\title{
Operationalizing the integrated landscape approach in practice
}

\author{
$\underline{\text { Olivia E. Freeman }}^{1}, \underline{\text { Lalisa A. Duguma }}^{1}$ and Peter A. Minang ${ }^{1}$
}

\begin{abstract}
The terms "landscape" and "landscape approach" have been increasingly applied within the international environmental realm, with many international organizations and nongovernmental organizations using landscapes as an area of focus for addressing multiple objectives, usually related to both environmental and social goals. However, despite a wealth of literature on landscapes and landscape approaches, ideas relating to landscape approaches are diverse and often vague, resulting in ambiguous use of the terms. Our aim, therefore, was to examine some of the main characteristics of different landscape approaches, focusing on how these might be applied in the process of taking a landscape approach. Drawing on a review of the literature, we identify and discuss three different kinds of landscape approaches: using the landscape scale, a sectoral landscape approach, and an integrated landscape approach. Focusing on an integrated landscape approach, we examine five concepts to help characterize landscape approaches: multifunctionality, transdisciplinarity, participation, complexity, and sustainability. For each term, a continuum of application exists. To help improve and move the integrated landscape approach more toward operationalization, more focus needs to be placed on the process of taking the approach. Although the process can be implemented in a range of ways, in a more integrated approach it will require explicitly defined objectives as well as a clear understanding of what is meant by multifunctionality and sustainability. It will also require collaborative participation, transdisciplinarity/cross-sectoral approaches, managing for adaptive capacity, and applying an iterative process to address the inherent complexity within the system. Although these concepts are not new, we present continuums on which they can exist, allowing for clarification and distinctions to be made regarding what it means to take a landscape approach.
\end{abstract}

Key Words: adaptive capacity; complex social-ecological systems; integrated landscape approach; multifunctionality; participation; sustainability; transdisciplinarity

\section{INTRODUCTION}

Taking a landscape approach is becoming a driving paradigm in the international environmental and development community. The concept is being embraced by large environmental nongovernmental organizations (NGOs) such as the World Wildlife Fund, the International Union for the Conservation of Nature, the African Wildlife Foundation, and Conservation International (Pressey and Bottrill 2009, Pfund 2010); international research organizations such as the World Agroforestry Centre and the Center for International Forestry Research; and international organizations such as the Food and Agriculture Organization of the United Nations, the World Bank, and the United Nations Environmental Programme. For example, the Convention on Biological Diversity adopted a set of landscape principles to "improve sustainable use of biodiversity in a landscape perspective” (UNEP 2011:1, Sayer et al. 2013). The inaugural Global Landscapes Forum, held alongside the United Nations Framework Convention on Climate Change Conference of Parties 19 in Warsaw, Poland, is further evidence of the growing importance of landscape approaches (CIFOR 2013).

The desire to holistically balance multiple goals related to both environmental and nonenvironmental processes, for example, livelihoods and sustainable resource management, has brought the focus to the landscape scale. Sectoral approaches for different land-use activities have largely dominated the resource management field, but have not reflected the multisectoral nature of most landscapes, which can include local communities, smallholder farms, protected areas, recreational activities, tourism enterprises, and/or resource industries such as agriculture, forestry, or mining (Frost et al. 2006, Bohnet and Smith 2007, Sayer et al. 2008, Scherr and McNeely 2008, Parrott and Meyer 2012). Therefore, a landscape approach generally tries to capture this additional complexity by viewing the landscape as a mosaic (Sayer 2005, Pfund et al. 2008, Sayer et al. 2008, Schaich et al. 2010) or as multifunctional (Naveh 2001, Termorshuizen and Opdam 2009, O'Farrell and Anderson 2010, Pearson and Gorman 2010).

One of the current discourses around landscapes is that integrated approaches are needed to address complex landscape-scale challenges (e.g., Sayer et al. 2013, Milder et al. 2014). Some have termed such challenges wicked problems (e.g., Balint et al. 2011, Sayer et al. 2013). Wicked problems can be described as unstructured problems that are hard to characterize and define. They require continuous decision making with no one clear solution, in part because of high levels of uncertainty and complexity, and processes that occur at different scales, involving a range of stakeholders with differing values (Rittel and Webber 1973, 1984, Weber and Khademian 2008, Balint et al. 2011). With an increasingly complex globalized world facing significant wicked environmental challenges, including climate change and feeding a growing global population, sustainably managing natural resources is as pertinent as ever. The landscape provides a scale for management that allows for a holistic view of the competing land-use interests and an understanding of inherent trade-offs within the system to better achieve multiple objectives connecting the local to the global.

Literature about landscape approaches is largely interdisciplinary, drawing on a wide range of concepts. These concepts draw on ideas from many research areas, such as landscape ecology (Wu and Hobbs 2002, Pearson and Gorman 2010, Pijanowski et al. 2010), biodiversity conservation (Chazdon et al. 2009, Pressey and Bottrill 2009, Romero et al. 2012), sustainability (Gómez-Sal 
et al. 2003, Musacchio 2009a, O'Farrell and Anderson 2010), ecosystem services (Sayer 2005, Ghazoul et al. 2009, Schaich et al. 2010), social sciences (Terkenli 2001, Field et al. 2003, Vaccaro and Norman 2008, Schaich et al. 2010), and complexity science (Naveh 2001, Parrott and Meyer 2012). However, despite the wealth of literature, with an increased rate of publications over the past decade (Fig. 1) and widespread international interest, what the landscape approach means in complex social-ecological systems is subject to a wide range of differing interpretations. This has led to what Sayer et al. (2013) describe as "constructive ambiguity," meaning that the general interpretation of the concept is appealing and widely used, but with no consensus about the details of what the term implies and represents, particularly in practice.

Fig. 1. Increases in the number of landscape-related publications over the past decade as demonstrated by two sets of search terms and the number of returned hits for each publication year within Google Scholar (searches were conducted on 14 October 2013).

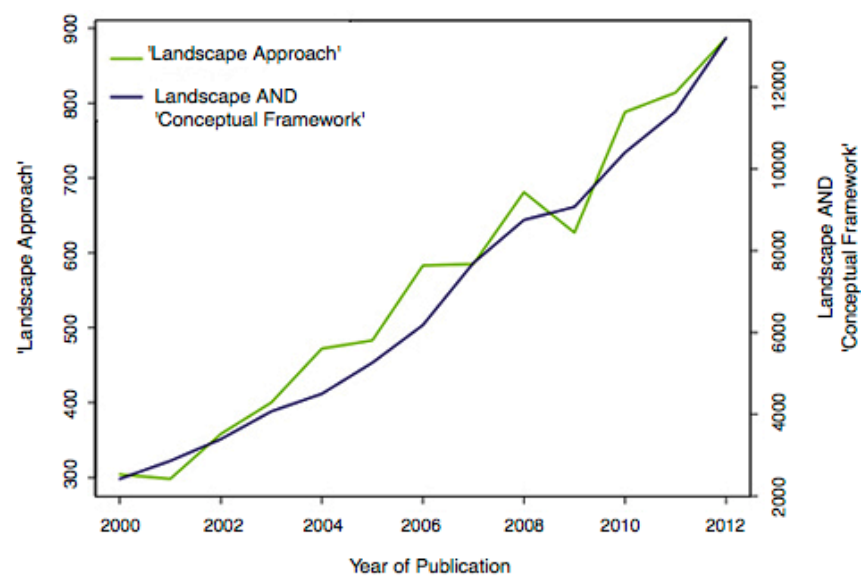

First looking at the terms "landscape" and "landscape approach," we make a distinction between three different types of landscape approaches. Focusing on what is termed an integrated landscape approach (ILA), we discuss what might be involved in the process of taking an ILA by drawing on a review of the literature and examining five concepts related to landscape approaches. Our aim was to further characterize some of the main concepts related to landscape approaches, making distinctions in the ways they can be applied in practice by focusing on the process of taking an ILA. Through such discussion, nuances in the way landscape approaches are described and interpreted are highlighted, adding to the conversation around what it means to take a landscape approach.

\section{DEFINING LANDSCAPES AND LANDSCAPE APPROACHES}

\section{Landscapes}

The word "landscape" existed prior to AD 1000 in its Old English form, landscipe, representing a region or extent of territory (James 1934). Since this time, many interpretations have been volunteered and applied. Both James (1934) and Vance (1929) discuss the natural and cultural dimensions of the landscape, with Vance also discussing the economic dimension. However, within the literature, these dimensions often are discussed separately and sometimes are framed as different landscapes entirely. Drawing strongly on the geography discipline, the concept of the cultural landscape was first defined in the 1890s (Jones 2003, as cited in Wu 2010), emerging in English-speaking countries in the 1920s (Schaich et al. 2010, Wu 2010). However, despite its early emergence as a concept, it has not gained strong dominance in the current discourse around landscape approaches, especially when compared with more ecologically based or integrated concepts (Schaich et al. 2010).

In comparison, the development of landscape ecology has provided the basis of many of the current ideas and discourses around landscape approach thinking. Coined in 1939 by a German geographer, Carl Troll, landscape ecology started to develop as an emerging discipline in the 1980s (Forman 1995a, $\mathrm{Wu}$ and Hobbs 2002). Two traditions or schools of landscape ecology, the European tradition and the North American tradition ( $\mathrm{Wu}$ and Hobbs 2002, Turner 2005, Wu 2006), distinguished themselves as the discipline developed, although they overlap at many points and the discipline now is largely a merger of the two (Wu 2013a). The European tradition is anthropogenic-centric and takes a more holistic approach, initially drawing strongly on concepts from planning ( Wu and Hobbs 2002, Turner 2005, Wu 2006; e.g., see Naveh and Lieberman 1984). In contrast, the North American school, including work from Australia, is more analytical, focusing on bioecological processes (Wu and Hobbs 2002, Turner 2005, Wu 2006). The work of the North American school is based largely on theories examining spatial patterns and ecological processes within the landscape, including the concepts of metapopulations, patch dynamics, and biological corridors, to name a few (Forman 1995a).

In two seminal books, a landscape is described as a land mosaic composed of spatial elements and ecological units defined by both structure and function, making up a matrix of patches (Forman and Godron 1981, 1986, Forman 1995b). Based on an ecological framing, Lindenmayer et al. (2008) state that a landscape can be classified by its structural attributes, habitat for a particular species, and functional attributes of landscape processes. In contrast, taking a holistic approach, Tress and Tress (2001) describe five dimensions of a landscape: (1) a spatial entity, (2) a mental entity, (3) a temporal dimension, (4) a nexus of nature and climate, and (5) a complex system. Along the same lines, Naveh (2001:269) describes multifunctional landscapes as "tangible, mixed natural and cultural interacting systems."

Many other diverse definitions have also been volunteered. Farina (2000:313) provides a description of cultural landscapes as "geographic areas in which the relations between human activity and the environment have created ecological, socioecononomic, and cultural patterns and feedback mechanisms that govern the presence, distribution, and abundance of species assemblages." In contrast the commonly cited Council of Europe's definition describes a landscape as "an area, as perceived by people, whose character is the result of the action and interaction of natural and/or human factors" (Council of Europe 2000:3). Physically, some have suggested defining landscapes at the regional scale 
Table 1. Three different kinds of landscape approaches. The focus in this paper is placed on the third, the integrated landscape approach (ILA).

\begin{tabular}{|c|c|c|c|}
\hline & Using the landscape scale & Sectoral landscape approach & $\begin{array}{l}\text { Integrated landscape approach } \\
\text { (ILA) }\end{array}$ \\
\hline Purpose/Approach & $\begin{array}{l}\text { Aim is to understand patterns and } \\
\text { processes at the landscape scale. }\end{array}$ & $\begin{array}{l}\text { Approaches the landscape with one } \\
\text { (to a few) primary goal(s) driving } \\
\text { the approach. Can include } \\
\text { secondary objectives. }\end{array}$ & $\begin{array}{l}\text { Framed around multifunctionality } \\
\text { and driven by participatory } \\
\text { transdisciplinary/cross-sectoral } \\
\text { processes. }\end{array}$ \\
\hline Process of the Approach & $\begin{array}{l}\text { Uses the landscape as a scale of } \\
\text { inquiry. } \\
\text { Does not include interdisciplinary } \\
\text { or participatory processes. }\end{array}$ & $\begin{array}{l}\text { Tends to use integrative } \\
\text { vs collaborative participatory } \\
\text { processes. }^{\dagger}\end{array}$ & $\begin{array}{l}\text { Uses transparent collaborative } \\
\text { participatory processes to } \\
\text { determine change logic and/or } \\
\text { clarify objectives. }\end{array}$ \\
\hline Examples & $\begin{array}{l}\text { Ecological management design; } \\
\text { informing research design (e.g., } \\
\text { Johnston et al. 1990, Viaud et al. } \\
\text { 2004). }\end{array}$ & $\begin{array}{l}\text { Primarily conservation driven } \\
\text { approaches (e.g., Sayer 2009); } \\
\text { watershed management; private } \\
\text { sector approaches for improving } \\
\text { supply chain efficiency (e.g., } \\
\text { Kissinger et al. 2013). }\end{array}$ & $\begin{array}{l}\text { Adaptive collaborative } \\
\text { management approach at the } \\
\text { landscape scale (e.g., Duff et al. } \\
\text { 2009); integrated landscape } \\
\text { initiatives (Milder et al. 2014). }\end{array}$ \\
\hline
\end{tabular}

${ }^{\dagger}$ See Duff et al. (2009) and the Participation section for distinction between integrative and collaborative participation.

(Gómez-Sal et al. 2003, Musacchio et al. 2009a, Pearson and Gorman 2010, Parrott and Meyer 2012) or encompassing an area of 1 hectare to $10,000 \mathrm{~km}^{2}$ (Pfund 2010, Angelstam et al. 2013, Milder et al. 2014).

Angelstam et al. (2013) outlines four categories of landscape interpretations: (1) the biophysical, viewing the landscape as only a natural phenomenon; (2) the anthropogenic, seeing the landscape as nature, but with some human constructions; (3) the intangible, with the landscape based on individual or social perceptions or interpretations; and (4) the coupled socialecological or integrated interpretation, viewing the landscape as a totality including natural, human, and spiritual dimensions. There has been a move toward the last interpretation in some scholarly work, although the spiritual dimension is often omitted (e.g., Naveh 2001, Tress and Tress 2001, Tress et al. 2001, Musacchio 2009a, $b$, Pijanoski et al. 2010).

This last integrated interpretation is the foundation for the conception of the landscape that we used. Both Sayer et al. (2013) and Milder et al. (2014) provide integrated definitions of a landscape, although their definitions vary from each other. In both cases, they state that to a large extent the landscape is context defined. Therefore, in the context of this paper a landscape can be defined as a complex social-ecological system, usually made up of a mosaic of different land uses. The boundaries of the landscape can either be discrete, for example, administrative boundaries, or fuzzy, for example, based on ecological units and/ or the extent of community activities resulting in a lack of a clear delineated boundary. In some cases there can also be multiple overlapping boundaries related to both social and ecological dimensions. The landscape itself will be largely context dependent, relating directly to the specific objectives outlined in the approach and their corresponding relevant spatial extent. Finally it should be added that in combining both social and ecological dimensions, spatially explicit patterns and processes and heterogeneity remain key defining characteristics of landscapes (Turner 1989, Pickett and Cadenasso 1995) and landscape approaches.

\section{Landscape approaches}

Just as there are many varying definitions and interpretations of landscapes, the term "landscape approach" also has been widely applied. For example, an Ecoagriculture Policy Focus brief provides a list of 80 terms related to integrated land management, many of which can be synonymous or overlap with the concept of a landscape approach (Scherr et al. 2013). In practice a large range of initiatives can be categorized under the umbrella of landscape approaches. Both Milder et al. (2014; 87 case studies) and Pfund (2010; 51 case studies) provide reviews of landscape approach case studies, termed integrated landscape initiatives by Milder et al. Furthermore, large NGOs and international organizations have a range of landscape-based initiatives such as the African Wildlife Foundation's priority landscapes (AWF 2014), the World Wildlife Fund's ecoregion-based priority landscapes (WWF 2014), the International Union for the Conservation of Nature's Livelihoods and Landscape Strategy launched in 2007 (IUCN 2014), the Consultative Group on International Agricultural Research's sentinel landscapes under the research program on forests, trees, and agroforestry (CIFOR 2014), Alternatives to Slash and Burn Partnership for the Tropical Forest Margins benchmark sites (ASB 2013a) and demonstration landscapes (ASB 2013b), the Congo Basin Forest Partnership 12 biodiversity landscapes (Central Africa Regional Program for the Environment; http://carpe.umd.edu/about/index.php), and the Satoyama Initiative's social-ecological production landscapes and seascapes (The International Partnership for the Satoyama Initiative; http://satoyama-initiative.org/about/).

Despite its wide application, clear definitions of what a landscape approach specifically means in practice are often lacking or vary across applied initiatives such as the ones listed in the previous paragraph. Drawing again on an integrated definition of a landscape, a landscape approach can generally be described as (1) addressing social-ecological systems at the landscape scale, (2) related to resource management and/or environmental goals, and (3) framed around the concept of multifunctionality, with the aim of achieving multiple objectives through the approach. Table 1 provides three different categories of landscape approaches. We 
Table 2. Three different framings of landscapes/landscape approaches in the literature.

\begin{tabular}{ll}
\hline \hline Different Framings & Description \\
\hline $\begin{array}{l}\text { Conceptual Framework } \\
\text {-Landscape }\end{array}$ & $\begin{array}{l}\text { Can be designed for the landscape itself or a landscape approach. Theoretically outlines the different } \\
\text {-Landscape Approach }\end{array}$ \\
$\begin{array}{l}\text { Principles } \\
\text {-Landscape Approach }\end{array}$ & $\begin{array}{l}\text { A set of principles or guidelines that a landscape approach should encompass, but does not specifically } \\
\text { outline the exact process and can be generalized to fit a range of different contexts. Applied and/or } \\
\text { theoretical. }\end{array}$ \\
$\begin{array}{l}\text { Process } \\
\text {-Landscape Approach }\end{array}$ & $\begin{array}{l}\text { A set of specific steps that the landscape approach should follow, e.g., conservation planning. } \\
\text { Determined by the context including driving objectives and relevant stakeholders. Will be subjective } \\
\text { depending on context. Application oriented. }\end{array}$ \\
\hline
\end{tabular}

focused predominantly on the third, the ILA, and how different concepts relate to the actual process of an ILA.

Although any organization applying a landscape approach probably will not describe it as simply using the landscape scale or taking a sectoral landscape approach, in practice these methods do occur sometimes under the auspices of an ILA. Although not comprehensive of all the different ways landscape approaches can be applied, using the landscape scale, a sectoral landscape approach, and an ILA are examples of different ways the term "landscape approach" can be applied and what it can encompass. The ILA is the most comprehensive and holistic of the three. On that basis, it might seem to be the most ideal, but the ILA may not always be possible if the commitment and capacity needed to effectively implement it are lacking. It is important to distinguish the ways in which the term "landscape" is used in each specific context to help make distinctions between different kinds of initiatives all categorizing themselves as a landscape approach or an ILA.

Similarly in the literature, researchers also focus on different dimensions of landscape approaches. Here we have broken these into three main categories or framings: conceptual frameworks for the landscape and/or landscape approach (e.g., Tress and Tress 2001, Pearson and Gorman 2010); a set of principles or guidelines for taking a landscape approach (e.g., Naveh 2001, Fischer et al. 2006, Sayer et al. 2013); and a description of the process of taking a landscape approach (e.g., Duff et al. 2009, Lovell and Johnston 2009, Pressey and Bottrill 2009; Table 2). Although these categories are not necessarily mutually exclusive, many articles focus on the former two, with less focus placed on the process of a landscape approach. Usually when landscape approaches are discussed in the literature, such distinctions are not made, but through our review of the literature these different framings were observed. The purpose of disaggregating them here is to demonstrate that all of these framings are important for taking a landscape approach, but in general less emphasis is placed on the actual process of taking a landscape approach within the literature. Therefore, we explore what might be involved in the process of taking an ILA by discussing five main characterizing concepts for landscape approaches.

\section{FIVE CHARACTERIZING CONCEPTS FOR AN INTEGRATED LANDSCAPE APPROACH}

To identify a main set of characterizing concepts of landscape approaches, we drew on a structured review of the literature and two articles. The structured review focused on papers that provided either (1) guidelines, principles, and/or lesson learned for landscape approaches and/or (2) a conceptual framework for landscape-scale approaches addressing some aspect of resource management, both within the context of social-ecological landscapes, excluding purely ecologically based or social-based approaches (see Appendix 1 for a detailed description of the methods). These papers represented a range of theories and conceptual framings of landscape approaches. Drawing on 6 cross-cutting concepts identified across the 43 articles reviewed, combined with other principles/characteristics derived from both expert insight (Sayer et al. 2013) and a review of applied case studies (Milder et al. 2014), we selected five main concepts. The review and the two articles are complementary. The review drew on different theories about landscape approaches; the first article reflected expert opinion; and the second article discussed landscape approaches in practice. Therefore, they broadly represent the convergence between the different ways of thinking about landscapes. We discuss the five concepts in the context of the process of taking an ILA.

Although it could be argued that Sayer et al. (2013) provides a more comprehensive list of principles or concepts to guide landscape approaches than the concepts chosen to be discussed here, we provide additional, different material that constructively contributes to the discussion. By focusing on more general concepts and highlighting the continuums in which each can be applied, we present additional considerations and distinctions for applying these concepts in practice.

Table 3 provides a summary of the different concepts identified in the literature review and two selected articles. Figure 2 provides a simplified comparison; the five concepts we selected for discussion are boldfaced. Multifunctionality, interdisciplinairty, participation, and complexity were chosen because they appear in two or three of the comparative works: the review and the two articles. Sustainability was included because in the literature review we observed that it was a term commonly included in either articles' titles and/or objectives, but often was not clearly defined. If sustainability is a potential goal of ILAs, what is meant by the term needs to be clearly defined to be achievable. For this reason, we included sustainabilty as one of the five concepts. Some discussion of the other nonboldfaced terms in Figure 2 is also included under the main five concepts. 
Table 3. Summary of the main concepts for landscapes approaches (or initiatives) identified in our review of the literature, Sayer et al. (2013), and Milder et al. (2014). Bolded concepts are the main ones identified for comparison (Fig. 2).

\begin{tabular}{|c|c|c|}
\hline $\begin{array}{l}\text { A Review of the Literature } \\
\text { (Our review) }\end{array}$ & $\begin{array}{l}\text { Expert Insight } \\
\text { (Sayer et al. 2013) }\end{array}$ & $\begin{array}{l}\text { Case Studies } \\
\text { (Milder et al. 2014) }\end{array}$ \\
\hline $\begin{array}{l}\text { We conducted a structured review of the } \\
\text { literature selecting } 43 \text { articles (see Appendix } 1 \\
\text { for methods). Although we reviewed a limited } \\
\text { number of articles compared to the extensive } \\
\text { literature that exists, the review focused } \\
\text { specifically on articles that were addressing } \\
\text { both environmental and social objectives and } \\
\text { providing a conceptual framework or set of } \\
\text { principles/guidelines. These articles represent } \\
\text { more theoretical/characterization literature } \\
\text { explicitly framed around social-ecological } \\
\text { landscape approaches. } \\
\text { The top six cross-cutting concepts identified } \\
\text { across the articles include: (1) complexity ( } 81 \% \text { ), } \\
\text { (2) interdisciplinarity or transdisciplinarity } \\
\text { (71\%), } \\
\text { (3) sustainability ( } 71 \% \text { ), } \\
\text { (4) participation (64\%), } \\
\text { (5) tradeoffs (45\%), and } \\
\text { (6) holism ( } 45 \% \text {; } \% \text { values represent the percent } \\
\text { of articles in the review in which the concept } \\
\text { was found present). }\end{array}$ & $\begin{array}{l}\text { Based upon both a review of the literature and } \\
\text { expert insight, Sayer et al. (2013:8349) provide } \\
\text { "Ten principles for a landscape approach to } \\
\text { reconciling agriculture, conservation, and other } \\
\text { competing land uses." These include: } \\
\text { 1. Continual learning and adaptive } \\
\text { management" } \\
\text { 2. Common concern entry point } \\
\text { 3. Multiple scales }{ }^{\dagger} \\
\text { 4. Multifunctionality } \\
\text { 5. Multiple stakeholders } \\
\text { 6. Negotiated and transparent change logic } \\
\text { 7. Clarifications of rights and responsibilities } \\
\text { 8. Participatory and user-friendly monitoring } \\
\text { 9. Resilience } \\
\text { 10. Strengthened stakeholder capacity } \\
\text { Though a rough characterization, the principles }^{\ddagger} \\
\text { with a }{ }^{\ddagger} \text { here are interpreted as relating to } \\
\text { participatory processes whereas the principles } \\
\text { with }{ }^{\dagger} \text { can all relate to different concepts around } \\
\text { complexity theory or complex systems. }\end{array}$ & $\begin{array}{l}\text { Milder et al. (2014:70) reviewed } 87 \text { case studies } \\
\text { in Africa of what they term, integrated } \\
\text { landscape initiatives. They define an integrated } \\
\text { landscape initiative as a “...project, program, } \\
\text { platform, initiative, or set of activities that: } \\
\text { (1) explicitly seeks to improve food production, } \\
\text { biodiversity or ecosystem conservation, and } \\
\text { rural livelihoods; } \\
\text { (2) works at a landscape scale and includes } \\
\text { deliberate planning, policy, management, or } \\
\text { support activities at this scale; } \\
\text { (3) involves inter-sectoral coordination or } \\
\text { alignment of activities, policies, or investments } \\
\text { at the level of ministries, local government } \\
\text { entities, farmer and community organizations, } \\
\text { NGOs, donors, and/or the private sector; and } \\
\text { (4) is highly participatory, supporting adaptive, } \\
\text { collaborative management within a social } \\
\text { learning framework." } \\
\text { The above points are interpreted to represent } \\
\text { the following concepts: } \\
\text { (1) multifunctionality; } \\
\text { (2) addressing the landscape scale; } \\
\text { (3) interdisciplinarity/cross-sectoral approaches; } \\
\text { and } \\
\text { (4) participation. }\end{array}$ \\
\hline
\end{tabular}

Fig. 2. Summary of main concepts identified in Table 3. The five concepts in bold are the focus of discussion in this paper.

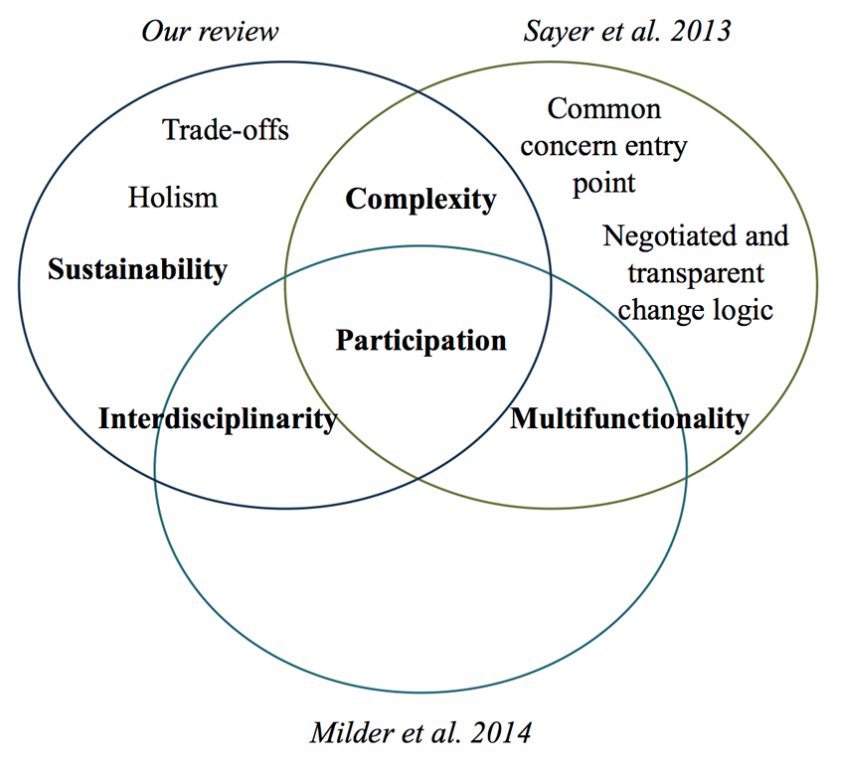

\section{Multifunctionality}

Multifunctionality can be described as achieving multiple objectives or functions at the same time. Multifunctionality in the context of landscape approaches is reflected by the multiple objectives of an ILA. These objectives are paramount because they largely define the landscape and the landscape approach. Furthermore, part of the rationale for taking a more systemsoriented view and using the landscape scale in landscape approaches is to be able to more effectively achieve multifunctionality by better recognizing and addressing both synergies and trade-offs.

One of the pitfalls of past integrated approaches has been not being able to effectively achieve multifunctionality or win-win goals (Tallis et al. 2008, Sayer 2009, McShane et al. 2011). Although sounding ideal, achieving win-win goals in practice has been challenging and an exception rather than then norm (Wells and McShane 2004, Tallis et al. 2008). In the context of biodiversity conservation and human well-being, McShane et al. (2011) describes meeting these dual objectives to be more about hard choices than win-win outcomes. Therefore, one of the challenges of ILAs is to go beyond past integrated approaches such as Integrated Conservation Development Projects, Integrated Natural Resource Management, Integrated Rural Development, and Integrated Water Resources Management. Instead of assuming win-win outcomes, ILAs should frame realistic objectives while recognizing trade-offs to be able to achieve multifunctionality within landscapes. 
These objectives may include a set of both primary and secondary objectives. The primary objectives drive the ILA and inform its design, with the secondary objectives factored in but not treated as driving priorities. For example, Harvey et al. (2013) focus on the synergies between two primary objectives, climate change mitigation and climate change adaptation. They also mention possible secondary objectives: food security, biodiversity conservation, and poverty alleviation. Similarly DeFries and Rosenzweig (2010:19631) focus on achieving both climate change mitigation and increasing food production, with mention of the possible secondary objectives of "biodiversity conservation, watershed protection, ecosystem services, and social and cultural aspects." As part of this process, it can prove constructive to address the four points highlighted by Mastrangelo et al. (2014), who examined landscape multifunctionality from the ecosystem services perspective. These are "(i) the multifunctionality of what ..., (ii) the type of multifunctionality ..., (iii) the procedure of multifunctionality assessments, and (iv) the purpose of multifunctionality" (Mastrangelo et al. 2014:345). Clarifying each of these points in an ILA will help to both guide the process delineating pathways of change and increase the chance of achieving the multiple objectives.

Part of the process will also require some form of participation to engage relevant stakeholders both within and outside the landscape. One way to engage stakeholders is through a commonconcern point of entry, which may involve first choosing an "easyto-reach intermediate target" to facilitate engagement and to start building trust through shared learning processes (Sayer et al. 2013:8351). Once engagement and a certain level of trust between stakeholders have been achieved, the focus can shift to working toward the primary objectives. This process can also be used to help define communal objectives among stakeholders (Stringer et al. 2006).

\section{Interdisciplinarity and transdisciplinarity}

One of the rationales for taking a landscape approach is to go beyond sectoral approaches to be able to better address multiple objectives within complex systems/landscapes. Though not synonymous, cross-sectoral approaches and interdisciplinary or transdisciplinary approaches engage stakeholders with different worldviews/expertise to achieve multifunctionality. Interdisciplinary approaches focus more on linking different research disciplines together; cross-sectoral approaches are based on multistakeholder processes relating more to practice. We link the two using Lattuca's (2003) continuum of interdisciplinarity as a basis. Table 4 outlines the kinds of research questions associated with each of the four different kinds of interdisciplinarity described by Lattuca (2003) and links them to cross-sectoral concepts within landscape approaches.

Here, we focus on transdisciplinarity because collaborative integrated approaches are needed to address complex landscapes. In our literature review, the papers that came closest to a transdisciplinary approach were those that focused on the management and/or the planning process itself. In these instances many stakeholders had to be involved in the process in order to, for example, review and assess different future landscape scenarios (Bohnet and Smith 2007), manage conflicting land values and land uses (Duff et al. 2009), or determine the most appropriate estuary-based enterprise activities in local communities (Bowd et al. 2012).

The process of transdisciplinarity could then follow two main trajectories: a research approach or a planning/management approach. Cross-sectoral approaches will likely involve some level of planning and engagement of stakeholders from different sectors both within and outside the landscape. For research-led approaches, this will involve action research, i.e., doing research across disciplines while at the same time working toward implementation of specific development objectives (Frost et al. 2006). The stakeholder or actor leading the approach will likely determine the kind of approach and the level of research involved. Furthermore, many argue that participatory approaches are needed to effectively address interdisciplinarity/transdisciplinarity to be inclusive of the multiple dimensions and interactions at the landscape scale (e.g., Sayer 2005, Pfund et al. 2008, Ghazoul et al. 2009, Musacchio 2009a, Milder et al. 2011, Bowd et al. 2012). Tools that can be used to help reconcile trade-offs include drawing on modeled scenarios and visioning future potential landscapes (Antrop 2006, Potschin and Haines-Young 2006, Bohnet and Smith 2007, Pearson and Gorman 2010, Klug 2012).

\section{Participation}

Participation, the only concept present across both articles and the review (Fig. 2), is directly aligned with the process of an ILA. However, although often quoted in a range of literature related to resource management, what participation looks like, who is involved, and what kind of processes should be applied are not often specified (Stringer et al. 2006). Some of the different kinds of participation include consultation, i.e., collecting information from targeted actors/stakeholders about their views on predetermined issues; engagement, which can be a form of consultation or bringing multiple actors together in a dialogue; social learning, i.e., opportunities for exchange of information and learning between stakeholders; and devolution, i.e., participants are given decision-making power. These kinds of participation can be integrated at different stages in planning and/ or management processes, e.g., defining objectives/management problems, planning, and monitoring (Stringer et al. 2006).

Duff et al. (2009) make a distinction between the kinds of participation to be facilitated. They advocate for collaborative participation that engages all stakeholders on equal levels instead of individually bringing their contributions to the table, i.e., an integrative approach, to avoid the disempowerment of alreadymarginalized stakeholders. Therefore, the process of participation has many implications for social power that need to be directly considered when designing and implementing participatory processes. Promoting social learning is one potential tool to reduce power dynamics between stakeholders. Within adaptive management cycles, Stringer et al. (2006) found that to promote social learning, participatory processed are needed that are iterative and flexible, promoting two-way flows of information and communication both across horizontal scales, e.g. across stakeholder groups, and vertical scales, e.g. across institutional levels. Although it does not necessarily make everyone agree on a shared set of values, social learning does have the potential to allow stakeholders to better understand each other's point of view and be more willing to work toward a more favorable outcome 
Table 4. The four types of interdisciplinarity described in Lattuca (2003)'s interdisciplinary continuum linked with how these might be applied in a landscape approach.

\begin{tabular}{|c|c|c|c|}
\hline Type of Scholarship & Research Questions & In a Landscape Approach & Example \\
\hline Informed Disciplinarity & $\begin{array}{l}\text { Disciplinary questions requiring } \\
\text { outreach to other disciplines }\end{array}$ & $\begin{array}{l}\text { Sectoral approaches that consider } \\
\text { activities of other sectors or other } \\
\text { dimensions in the landscape }\end{array}$ & $\begin{array}{l}\text { Private sector approaches to reduce } \\
\text { risk by making their value chains } \\
\text { more efficient, focusing on their } \\
\text { specific commodity but considering } \\
\text { other influencing factors at the } \\
\text { landscape scale (e.g., Kissinger et } \\
\text { al. 2013). }\end{array}$ \\
\hline Synthetic Interdisciplinarity & Questions that link disciplines & $\begin{array}{l}\text { Approaches that link sectors with } \\
\text { multiple sector-based objectives }\end{array}$ & $\begin{array}{l}\text { Approaches with primary } \\
\text { objectives such as water provision } \\
\text { and maintaining biological } \\
\text { corridors that recognizes other } \\
\text { dimensions in the landscapes, such } \\
\text { as farmer's activities, but only } \\
\text { addresses these dimensions to the } \\
\text { extent that they impact the } \\
\text { outcomes of the driving objectives } \\
\text { (e.g., Sayer 2009). }\end{array}$ \\
\hline Transdisciplinarity & Questions that cross disciplines & $\begin{array}{l}\text { Cross-sectoral approaches } \\
\text { addressing cross-sectoral objectives } \\
\text { using multistakeholder/ } \\
\text { participatory processes }\end{array}$ & $\begin{array}{l}\text { Looking for synergistic adaption } \\
\text { and mitigation options (primary } \\
\text { objectives) across a range of land } \\
\text { uses with impacts for water supply, } \\
\text { food production, livelihoods, and } \\
\text { biodiversity (relating to secondary } \\
\text { objectives) with varying } \\
\text { stakeholder interests (e.g., Harvey } \\
\text { et al. 2013). }\end{array}$ \\
\hline Conceptual Interdisciplinarity & $\begin{array}{l}\text { Questions without a compelling } \\
\text { disciplinary basis }\end{array}$ & $\begin{array}{l}\text { Collaborative approach defining } \\
\text { objectives through the process itself } \\
\text { without a specific initial framing }\end{array}$ & $\begin{array}{l}\text { Envisioning future scenarios in a } \\
\text { landscape through participatory } \\
\text { processes with stakeholders } \\
\text { determining which projection they } \\
\text { would like to follow (e.g., Bohnet } \\
\text { and Smith 2007). }\end{array}$ \\
\hline
\end{tabular}

for all (Stringer et al. 2006). Integrating both local and/or indigenous and scientific knowledge can also greatly contribute to this process.

Challenges for using participatory processes include (1) they will have to be to some extent context defined, with different possible kinds of participation at different stages in the management/ planning process, i.e., there can be no specific, formulaic guidelines for participation in an ILA; and (2) they will often need a specific set of enabling factors to allow for effective participation. Potential enabling factors include the presence or creation of a neutral facilitator and/or boundary institutions that stakeholders can trust to facilitate participatory processes, and sufficient funds over a long enough time frame to support both the management/planning and participatory activities. There will also need to be significant buy-in from major stakeholders involved. If certain stakeholders choose to exercise a disproportionate amount of power to advance their interests, then such participatory and collaborative management processes may not be possible. First, the majority of relevant stakeholders will need to have a basic level of interest and willingness to engage. Having a common-concern entry point as described by Sayer et al. (2013) could help to assist in this process.

For effective participatory process in an ILA, it is important to define what participation means in the specific context.
Answering the following questions can assist in this process: where, i.e., in what stage of the ILA; how, i.e., what kind of participatory activities; and for whom, i.e., who is to be involved and why, including considerations of social power dynamics. Including both collaborative processes and social learning could greatly strengthen management outcomes as long as the capacity to implement such processes is present.

\section{Complexity}

Landscapes can be described as complex social-ecological systems made up of a range of different processes occurring on different scales. Seeing the landscape as an emergent whole instead of the sum of its parts is part of the holism versus reductionism debate within systems-thinking literature (Wu and Loucks 1995, Jackson 2006, Zexian and Xuhui 2010). However, holism and reductionism are not necessarily mutually exclusive, and as Jackson (2006) states, both can be used complementarily. Looking at a landscape does require taking a holistic view while at the same time addressing the specific parts that make up the whole. The emergent patterns and processes making up the whole within a landscape are part of the inherent complexity of such systems.

The interactions within and between social and ecological systems create a number of patterns and processes at the landscape scale. In large part, these are defined by the spatially heterogeneity of the landscape, which is usually made up a number of different 
land uses and land cover types. The way that the different units within the landscape are arranged and managed has huge implications for emergent landscape properties. For example, creating buffer zones and biological and/or wildlife corridors can greatly enhance biodiversity and ecosystem functioning within a landscape, the lack of which can have isolating and detrimental effects. Therefore, being able to understand such spatially explicit patterns and processes is a key part of being able to address drivers of change and manage complexity.

Drawing on concepts from complexity science, Parrott and Meyer (2012) present five succinct recommendations to address complex landscape systems: (1) work with a conceptual model of the landscape as a complex system; (2) understand and document emergent patterns and processes by monitoring the landscape at multiple spatial and temporal scales; (3) build and maintain adaptive capacity to buffer against change; (4) take advantage of the system's internal memory, i.e., mimic natural processes; and (5) work with envelopes of possibilities and alternative futures.

These recommendations are strongly linked to Panarchy theory, which outlines a framework for understanding and interpreting complex social-ecological systems (Holling 2001, Gunderson and Holling 2002). According to this theory, in dynamic, uncertain systems overall adaptive capacity can be promoted by strengthening three general areas: potential, i.e., the "wealth" of the system, which can allow for change; connectedness, i.e., controllability of the system, which determines flexibility or rigidity of connectedness; and resilience, i.e., the adaptive capacity or measure of vulnerability. Adaptive capacity combined with opportunities will then foster the environment for holistic sustainable development, the basis for Parrott and Meyer's (2012) third recommendation. This will also, according to Jackson et al. (2010), allow for "sustainagility" versus other more mainstream conceptions of sustainability; see the Sustainability section.

In the process of the landscape approach, specific primary objectives will require looking at specific parts of the landscape, e.g., forested areas and/or agricultural production areas. At the same time, the emergent whole also needs to be assessed to effectively address drivers within the landscape. For example, in the case of addressing deforestation, it has been recognized that most of the drivers of deforestation occur outside of the forest area (Geist and Lambin 2002, Hosonuma et al. 2012), thereby requiring a more holistic approach encompassing a larger scale to effectively address such drivers instead of focusing solely on the forest alone (Bernard et al. 2013).

To be able to address drivers in the landscape, levers of change will need to be identified by understanding the parts that make up the whole, the interactions between the parts, and the emergent whole. See Parrott and Meyer's (2012) conceptual diagram of a complex social-ecological system. Part of this will include understanding both spatially explicit patterns and processes within the landscape. In this process both adaptive flexibility and a certain level of structure are needed. In a review of four NGOs' conservation activities, Pressey and Bottrill (2009) found that although all NGOs had varying approaches, systematic methods had significant benefits in the planning process. At the same time, it will be essential to respond to change through an iterative process. Concepts such as action research (Frost et al. 2006, Sayer et al. 2008, O'Farrell and Anderson 2010), social learning (Frost et al. 2006, Stringer et al. 2006, Bohnet and Smith 2007, Sayer et al. 2008, Milder et al. 2011, Bowd et al. 2012), and adaptive management (Frost et al. 2006, Pfund et al. 2008, Chazdon et al. 2009, Duff et al. 2009, Pfund 2010) have been suggested as tools to foster such an approach. Sayer et al. 's (2013) sixth principle, having a negotiated and transparent change logic involving a theory of change, i.e., a logic model of how to get from point $\mathrm{A}$ to point B or how to instigate desired change within the system over a specified period of time, can be one potential tool to balance both a structured approach and "muddling through" (Sayer et al. 2008, 2013). This change logic ideally will be developed and agreed on by all stakeholders involved in the process.

\section{Sustainability}

The terms "sustainability" and "sustainable landscapes" are widely applied. Wu (2013b) provides a comprehensive summary of five types of sustainability in the context of landscapes: the Brundtland definition, the triple bottom line, weak versus strong sustainability, human well-being, and ecosystem services. Here we draw on some of these concepts focusing on an adaptive approach to sustainability.

In the range of interpretations of sustainability, Robinson (2004) points to two main distinctions: sustainability and sustainable development. Both of these terms can be related to the Brundtland Commission's definition of sustainability: "meets the needs of current generations without compromising the ability of future generation to meet their own needs"(World Commission on Environment and Development 1987:23). According to Robinson (2004:370), sustainability focuses on "the ability of humans to continue to live within environmental constraints," whereas sustainable development focuses on the radical message of the Commission: the environment cannot be addressed without simultaneously addressing social conditions requiring growth to improve livelihoods. The definition of sustainable development has been embraced in economic policy and recognized as a dominant definition of sustainability within government and the private sector (Pearce 2002). This notion has been extended as a founding theoretical framework for many international development initiatives, with a focus on integrating social, environmental, and economic dimensions to reach development goals (e.g., World Bank 2001; Division for Sustainable Development, United Nations Department of Economic and Social Affairs, http://sustainabledevelopment.un.org/about. html). Since then many models of sustainability have been created (see Wu 2013b); one of the better known ones is the sustainability stool resting on three legs: social, economic, and environmental (Robinson 2004), a.k.a., the triple bottom line (Wu 2013b).

Both Antrop (2006) and Jackson et al. (2010) state that these interpretations of sustainability do not account for the dynamic nature of social-ecological systems. Antrop (2006) found that natural and human capital-based landscape approaches are too economically driven to foster strong sustainability operating within environmental limits versus weak sustainability, focusing on sustainable growth without recognizing environmental limits; see Ekins et al. (2003) and $\mathrm{Wu}$ (2013b) for further discussion. On the other hand, the preservation of landscape qualities indicates that the landscape usually is being addressed in parts, not as an integrated whole. To have a truly holistic approach for landscape sustainability, emergent properties and landscape states need to 
Table 5. Continuums for each of the five concepts discussed. Some are more developed than others, for example Lattuca's (2003) continuum for interdisciplinarity vs the rough comparison for complexity, but the overall objective of this table is to demonstrate the range of application for each of the concepts. In an integrated landscape approach (ILA), ideally more of these concepts will be engaged toward the right end of the table, but will be largely dependent on the capacity and interest that exists. See sections on each concept for more details about each.

\begin{tabular}{|c|c|c|c|c|}
\hline \multicolumn{5}{|c|}{ Continuums of Concepts } \\
\hline Multifunctionality & $\begin{array}{l}\text { Sectoral approach with one-few } \\
\text { primary objectives }\end{array}$ & & & $\begin{array}{l}\text { Multiple primary objectives and } \\
\text { secondary objectives crossing } \\
\text { multiple sectors/disciplines }\end{array}$ \\
\hline & [Sectoral/ Monofunctionality] & $->$ & $->$ & [Integrative/ Multifunctionality] \\
\hline Participation & $\begin{array}{l}\text { No or low one-way } \\
\text { participation (e.g., consultation) }\end{array}$ & $\begin{array}{l}\text { Integrative } \\
\text { participation }\end{array}$ & $\begin{array}{l}\text { Collaborative horizontal } \\
\text { participation }\end{array}$ & $\begin{array}{l}\text { Vertical and horizontal } \\
\text { collaborative participation }\end{array}$ \\
\hline Interdisciplinarity & Informed disciplinarity & $\begin{array}{l}\text { Synthetic } \\
\text { interdisciplinarity }\end{array}$ & Transdisciplinarity & Conceptual interdisciplinarity \\
\hline Sustainability & $\begin{array}{l}\text { Weak and/or static } \\
\text { sustainability }\end{array}$ & The & $->$ & $\begin{array}{l}\text { Strong and/or iterative } \\
\text { sustainability (i.e., sustainagility) }\end{array}$ \\
\hline Complexity & $\begin{array}{l}\text { No adaptive capacity in } \\
\text { approach (e.g., managing for } \\
\text { current trajectories) }\end{array}$ & $->$ & $->$ & $\begin{array}{l}\text { Adaptive/ iterative approach (e.g., } \\
\text { adaptive management: managing } \\
\text { for changing dynamic future } \\
\text { states) }\end{array}$ \\
\hline
\end{tabular}

be managed as changing, nonstatic entities. Jackson et al. (2010) draw on similar concepts framing the idea of "sustainagility," which emphasizes the need to manage for adaptive capacity and not just persistence of current trajectories. Following these arguments, systems will have to adapt functions to changing conditions for healthy ecosystems to be truly sustainable. This process will involve considering trade-offs at multiple scales.

Similar sentiments are discussed by Wu (2013b:1013), who describes a working definition of landscape sustainability as "the capacity of a landscape to consistently provide long-term, landscape-specific ecosystem services essential for maintaining and improving human well-being in a regional context and despite environmental and sociocultural changes." Part of this process involves strengthening resilience and reducing vulnerability.

In the process of a landscape approach, what is meant by sustainability should be explicitly stated, especially if included as either a primary or a secondary objective. It is essential to address the questions of what is being sustained, why it is being sustained, and at what scales it is being sustained. Adaptive management, an iterative process of treating policies and interventions like experiments and using outcomes to inform future decisions (Holling 1978, Walters 1986), can be used to facilitate adaptive capacity to help manage for "sustainagility," with the idea that this will create stronger outcomes that meet multifunctionality objectives.

\section{OPERATIONALIZING THE INTEGRATED LANDSCAPE APPROACH}

In the process of taking an ILA, there is a need to balance both structure and adaptive flexibility. The overarching goal is to create multifunctionality, but beyond this, landscape approaches will be largely context dependent. When comparing the different kinds of landscape approaches in Table 2, the ILA is the most comprehensive, with the strongest focus on achieving mulitfunctionality as part of its objectives. However, it is also the most demanding regarding the process, requiring engagement across disciplines and/or sectors, as well as the facilitation of collaborative participatory processes. Furthermore, because it is in part context dependent, there is no one clear road map for how to take an ILA.

Despite this, the discussion of the five previously outlined concepts highlights some of the considerations that need to be made in the ILA process. To start, objectives need to be clearly defined in such a way that they are both achievable and measureable. This will likely involve both primary and secondary objectives. Achievement of multifunctionality will then involve compromise and a certain number of trade-offs. Identifying levers to address drivers within the landscape to create favorable change will be part of this process. Using transdisciplinary or crosssectoral approaches can allow integrated thinking and collaboration to occur and can help to minimize the number of trade-offs. Participatory approaches will be a key part of the process, but exactly what kind of participation will be largely context dependent. Processes that involve collaborative engagement and social learning, and reduce potential marginalization of stakeholders by accounting for social power dynamics are ideal. For complexity and sustainability, using an adaptive management approach to promote both adaptive capacity and "sustainagility" will help to encompass and address a certain level of complexity while also more effectively addressing sustainability. Lastly, if sustainability is included as an objective, it needs to be clearly defined.

Although these concepts sound theoretically appealing, applying them in practice will be challenging. In some cases, an ILA will not always be realistic; instead, a sectoral landscape approach (see Table 2) may be more appropriate based on the resources and capacity present. Either way, when taking a landscape approach, the extent to which it is integrated should be examined. When applying the five concepts discussed, a continuum of application for each exists (Table 5). Engaging in processes toward the right side of the spectrum is ideal, promoting more integration within the approach, but again this engagement may be limited by resources and capacity. 
If taking an ILA, having both a structured conceptual framework of the landscape and landscape approach as well as a "negotiated and transparent change logic" (Sayer et al. 2013:8351) or theory of change can help to provide structure for the approach, while including iterative, adaptive processes within this structured design to allow for a certain level of learning by doing or muddling through. Seeing the landscape as a complex system such as outlined by Parrott and Meyer (2012) is one potential conceptual framework that can be applied.

More research is needed using indicators to monitor and evaluate both the processes and outcomes of sectoral landscape approaches and ILAs, focusing specifically on the degree to which multifunctionality has been achieved. Furthermore, more attention needs to be paid to participatory and transdisciplinary/ cross-sectoral approaches to better understand how these processes can shape and define the ILA in practice; detailed cases studies of these approaches are needed.

\section{CONCLUSION}

The application of a landscape approach can widely vary in its focus, approach, and what it encompasses. Although sometimes a more sectoral landscape approach may be the most realistic choice because of limitations in capacity, the ILA holds much more potential to effectively address multiple objectives and in some cases wicked problems. To successfully achieve the desired multifunctionality in a landscape approach, more attention needs to be paid to how the process of taking an ILA is both designed and implemented. As part of this process, a continuum of application exists for five of the characterizing concepts: multifunctionality, transdisciplinarity, participation, complexity, and sustainability. To move toward a truly integrated landscape approach, the nuances of application for each of these concepts need to be examined and accounted for.

Although there is still much more to be learned through actual application of such processes, the first step is recognizing the multiple dimensions of each of these concepts and how different levels of application of each can lead to very different outcomes, all under the same auspices of taking a landscape approach. More effort and attention are needed to move toward operationalizing truly integrated landscape approaches in practice.

Responses to this article can be read online at: http://www.ecologyandsociety.org/issues/responses. $\mathrm{php} / 7175$

\section{Acknowledgments:}

The ideas within this paper were developed over time, in part on through a number of casual exchanges with colleagues. A writeshop at the Bellagio Rockefeller Center was especially constructive in this process, including critical feedback from Celia A. Harvey. Additionally, the authors would like to acknowledge the input, support, and ideas of Todd S. Rosenstock, Mehmood U. I. Hassan, and Florence Bernard on earlier versions of the manuscript. Last but not least, the authors would like to recognize the important feedback from the editor and the two anonymous reviewers whose comments proved greatly constructive. This work was made possible by the Government of Norway (Norwegian International Climate and Forest Initiative/Norwegian Agency for Development), the Consultative Group on International Agricultural Research research program on Forests, Trees and Agroforestry, and the International Institute for Sustainable Development Young Leaders for a Sustainable Future Program.

\section{LITERATURE CITED}

African Wildlife Foundation (AWF). 2014. Where we work. AWF, Nairobi, Kenya. [online] URL: http://www.awf.org/where-wework

Angelstam, P., M. Grodzynskyi, K. Andersson, R. Axelsson, M. Elbakidze, A. Khoroshev, I. Kruhlov, and V. Naumov. 2013. Measurement, collaborative learning and research for sustainable use of ecosystem services: landscape concepts and Europe as laboratory. Ambio 42(2):129-145. http://dx.doi.org/10.1007/ s13280-012-0368-0

Antrop, M. 2006. Sustainable landscapes: contradiction, fiction or utopia? Landscape and Urban Planning 75(3-4):187-197. http:// dx.doi.org/10.1016/j.landurbplan.2005.02.014

ASB Partnership for the Tropical Forest Margins (ASB). $2013 b$. Architecture of REALU: reducing emissions from all land uses. ASB, Nairobi, Kenya. [online] URL: http://www.asb.cgiar.org/ content/realu-reducing-emissions-all-land-uses

ASB Partnership for the Tropical Forest Margins (ASB). $2013 a$. ASB benchmark sites. ASB, Nairobi, Kenya. [online] URL: $\underline{\text { http:// }}$ www.asb.cgiar.org/asb-benchmark-sites

Balint, P. J., R. E. Stewart, A. Desai, and L. C. Walters. 2011. Wicked environmental problems: managing uncertainty and conflict. Island Press, Washington, D.C., USA. http://dx.doi. org/10.5822/978-1-61091-047-7

Bernard, F., P. A. Minang, M. van Noordwijk, O. E. Freeman, and L. A. Duguma, editors. 2013. Towards a landscape approach for reduction emissions: a substantive report of The Reducing Emissions from All Land Uses (REALU) project. World Agroforestry Centre-ICRAF, Nairobi, Kenya. [online] URL: http://asb.cgiar.org/PDFwebdocs/Substantive $\% 20$ Global $\%$ 20Report_REALU\%20II_FINAL_15nov_2 standard.pdf

Bohnet, I., and D. M. Smith. 2007. Planning future landscapes in the Wet Tropics of Australia: a social-ecological framework. Landscape and Urban Planning 80(1-2):137-152. http://dx.doi. org/10.1016/j.landurbplan.2006.07.001

Bowd, R., N. Quinn, D. C. Kotze, D. G. Hay, and M. Mander. 2012. The identification of potential resilient estuary-based enterprises to encourage economic empowerment in South Africa: a toolkit approach. Ecology and Society 17(3): 15. http:// dx.doi.org/10.5751/ES-04840-170315

Chazdon, R. L., C. A. Harvey, O. Komar, D. M. Griffith, B. G. Ferguson, M. Martínez-Ramos, H. Morales, R. Nigh, L. SotoPinto, M. van Breugel, and S. M. Philpott. 2009. Beyond reserves: a research agenda for conserving biodiversity in human-modified tropical landscapes. Biotropica 41(2):142-153. http://dx.doi. org/10.1111/j.1744-7429.2008.00471.x 
Center for International Forestry Research (CIFOR). 2013. Global landscapes forum: final report. UNFCCC COP 19 Warsaw, Poland, November 16-17. CIFOR, Bogor, Indonesia. [online] URL: http://www.landscapes.org/wp-content/uploads/2014/documents/ GLF-FinalReport en.pdf

Center for International Forestry Research (CIFOR). 2014 Sentinel landscapes. CIFOR, Bogor, Indonesia. [online] URL: http://www.cifor.org/sentinel-landscapes/home.html

Council of Europe. 2000. European landscape convention. European Treaty Series No. 176. Council of Europe, Strasboug, France. [online] URL: http://conventions.coe.int/Treaty/en/ Treaties/Html/176.htm

DeFries, R., and C. Rosenzweig. 2010. Toward a whole-landscape approach for sustainable land use in the tropics. Proceedings of the National Academy of Sciences of the United States of America 107(46):19627-19632. http://dx.doi.org/10.1073/pnas.1011163107

Duff, G., D. Garnett, P. Jacklyn, J. Landsberg, J. Ludwig, J. Morrison, P. Novelly, D. Walker, and P. Whitehead. 2009. A collaborative design to adaptively manage for landscape sustainability in north Australia: lessons from a decade of cooperative research. Landscape Ecology 24(8):1135-1143. http:// dx.doi.org/10.1007/s10980-008-9236-5

Ekins, P., S. Simon, L. Deutsch, C. Folke, and R. De Groot. 2003. A framework for the practical application of the concepts of critical natural capital and strong sustainability. Ecological Economics 44(2-3):165-185. http://dx.doi.org/10.1016/S0921-8009 (02)00272-0

Farina, A. 2000. The cultural landscape as a model for the integration of ecology and economics. BioScience 50(4):313-320. http://dx.doi.org/10.1641/0006-3568(2000)050[0313:TCLAAM]2.3. $\mathrm{CO} ; 2$

Field, D. R., P. R. Voss, T. K. Kuczenski, R. B. Hammer, and V. C. Radeloff. 2003. Reaffirming social landscape analysis in landscape ecology: a conceptual framework. Society \& Natural Resources 16(4):349-361. http://dx.doi.org/10.1080/08941920390178900

Fischer, J., D. B. Lindenmayer, and A. D. Manning. 2006. Biodiversity, ecosystem function, and resilience: ten guiding principles for commodity production landscapes. Frontiers in Ecology and the Environment 4(2):80-86. http://dx.doi. org/10.1890/1540-9295(2006)004[0080:BEFART]2.0.CO;2

Forman, R. T. T. 1995b. Land mosaics: the ecology of landscapes and regions. Cambridge University Press, Cambridge, UK.

Forman, R. T. T. 1995a. Some general principles of landscape and regional ecology. Landscape Ecology 10(3):133-142. http:// dx.doi.org/10.1007/BF00133027

Forman, R. T. T., and M. Godron. 1981. Patches and structural components for a landscape ecology. BioScience 31(10):733-740. http://dx.doi.org/10.2307/1308780

Forman, R. T. T., and M. Godron. 1986. Landscape ecology. John Wiley and Sons, New York, New York, USA.

Frost, P., B. Campbell, G. Medina, and L. Usongo. 2006. Landscape-scale approaches for integrated natural resource management in tropical forest landscapes. Ecology and Society 11
(2): 30. [online] URL: http://www.ecologyandsociety.org/vol11/ iss $2 / \operatorname{art} 30 /$

Geist, H. J., and E. F. Lambin, 2002. Proximate causes and underlying driving forces of tropical deforestation: tropical forests are disappearing as the result of many pressures, both local and regional, acting in various combinations in different geographical locations. BioScience 52(2):143-150. http://dx.doi.org/10.1641/0006-3568 (2002)052[0143:PCAUDF]2.0.CO;2

Ghazoul, J., C. Garcia, and C. G. Kushalappa. 2009. Landscape labelling: a concept for next-generation payment for ecosystem service schemes. Forest Ecology and Management 258 (9):1889-1895. http://dx.doi.org/10.1016/j.foreco.2009.01.038

Gómez-Sal, A., J.-A. Belmontes, and J.-M. Nicolau. 2003. Assessing landscape values: a proposal for a multidimensional conceptual model. Ecological Modelling 168(3):319-341. http:// dx.doi.org/10.1016/S0304-3800(03)00144-3

Gunderson, L., and C. S. Holling. 2002. Panarchy: understanding transformations in human and natural systems. Island Press, Washington D.C., USA.

Harvey, C. A., M. Chacón, C. I. Donatti, E. Garen, L. Hannah, A. Andrade, L. Bede, D. Brown, A. Calle, J. Chará, C. Clement, E. Gray, M. H. Hoang, P. Minang, A. M. Rodríguez, C. SeebergElverfeldt, B. Semroc, S. Shames, S. Smukler, E. Somarriba, E. Torquebiau, J. van Etten, and E. Wollenberg. 2014. Climate-smart landscapes: opportunities and challenges for integrating adaptation and mitigation in tropical agriculture. Conservation Letters 7(2):77-90. http://dx.doi.org/10.1111/conl.12066

Holling, C. S. 1978. Adaptive environmental assessment and management. John Wiley and Sons, New York, New York, USA.

Holling, C. S. 2001. Understanding the complexity of economic, ecological, and social systems. Ecosystems 4(5):390-405. http:// dx.doi.org/10.1007/s10021-001-0101-5

Hosonuma, N., M. Herold, V. De Sy, R. S. De Fries, M. Brockhaus, L. Verchot, A. Angelsen, and E. Romijn, 2012. An assessment of deforestation and forest degradation drivers in developing countries. Environmental Research Letters 7 (4):044009. http://dx.doi.org/10.1088/1748-9326/7/4/044009

International Union for the Conservation of Nature (IUCN). 2014. Livelihoods and landscapes strategy. IUCN, Gland, Switzerland. [online] URL: http://www.iucn.org/about/work/ programmes/forest/fp our work/fp projects/fp our work 11/

Jackson, L., M. van Noordwijk, J. Bengtsson, W. Foster, L. Lipper, M. Pulleman, M. Said, J. Snaddon, and R. Vodouhe. 2010. Biodiversity and agricultural sustainagility: from assessment to adaptive management. Current Opinion in Environmental Sustainability 2(1):80-87. http://dx.doi.org/10.1016/j.cosust.2010.02.007

Jackson, M. C. 2006. Creative holism: a critical systems approach to complex problem situations. Systems Research and Behavioral Science 23(5):647-657. http://dx.doi.org/10.1002/sres. 799

James, P. E. 1934. The terminology of regional description. Annals of the Association of American Geographers 24(2):78-92. http:// dx.doi.org/10.1080/00045603409357125 
Johnston, C. A., N. E. Detenbeck, and G. J. Niemi. 1990. The cumulative effect of wetlands on stream water quality and quantity. A landscape approach. Biogeochemistry 10(2):105-141. http://dx.doi.org/10.1007/BF00002226

Kissinger, G., A. Brasser, and L. Gross. 2013. Reducing risk: landscape approaches to sustainable sourcing synthesis report. EcoAgriculture Partners 1-35.

Klug, H. 2012. An integrated holistic transdisciplinary landscape planning concept after the Leitbild approach. Ecological Indicators 23:616-626. http://dx.doi.org/10.1016/j.ecolind.2012.05.019

Lattuca, L. R. 2003. Creating interdisciplinarity: grounded definitions from college and university faculty. History of Intellectual Culture 3(1):1-20.

Lindenmayer, D., R. J. Hobbs, R. Montague-Drake, J. Alexandra, A. Bennett, M. Burgman, P. Cale, A. Calhoun, V. Cramer, P. Cullen, D. Driscoll, L. Fahrig, J. Fischer, J. Franklin, Y. Haila, M. Hunter, P. Gibbons, S. Lake, G. Luck, C. MacGregor, S. McIntyre, R. MacNally, A. Manning, J. Miller, H. Mooney, R. Noss, H. Possingham, D. Saunders, F. Schmiegelow, M. Scott, D. Simberloff, T. Sisk, G. Tabor, B. Walker, J. Wiens, J. Woinarski, and E. Zavaleta. 2008. A checklist for ecological management of landscapes for conservation. Ecology Letters 11(1):78-91. http:// dx.doi.org/10.1111/j.1461-0248.2007.01114.X

Lovell, S. T., and D. M. Johnston. 2009. Creating multifunctional landscapes: how can the field of ecology inform the design of the landscape? Frontiers in Ecology and the Environment 7(4):212-220. http://dx.doi.org/10.1890/070178

Mastrangelo, M. E., F. Weyland, S. H. Villarino, M. P. Barral, L. Nahuelhual, and P. Laterra. 2014. Concepts and methods for landscape multifunctionality and a unifying framework based on ecosystem services. Landscape Ecology 29(2):345-358. http://dx. doi.org/10.1007/s10980-013-9959-9

McShane, T. O., P. D. Hirsch, T. C. Trung, A. N. Songorwa, A. Kinzig, B. Monteferri, D. Mutekanga, H. V. Thang, J. L. Dammert, M. Pulgar-Vidal, M. Welch-Devineh, J. P. Brosiush, P. Coppolillog, and S. O'Connor. 2011. Hard choices: making tradeoffs between biodiversity conservation and human well-being. Biological Conservation 144(3):966-972. http://dx.doi.org/10.1016/ j.biocon.2010.04.038

Milder, J. C., L. E. Buck, F. DeClerck, and S. J. Scherr. 2011. Landscape approaches to achieving food production natural resource conservation, and the millennium development goal. Pages 77-108 in J. C. Ingram, F. DeClerck, and C. Rumbaitis del Rio, editors. Integrating ecology and poverty reduction. Springer, Boston, Massachusetts, USA.

Milder, J. C., A. K. Hart, P. Dobie, J. Minai, and C. Zaleski. 2014. Integrated landscape initiatives for African agriculture, development, and conservation: a region-wide assessment. World Development 54:68-80. http://dx.doi.org/10.1016/j.worlddev.2013.07.006

Musacchio, L. R. 2009b. The ecology and culture of landscape sustainability: emerging knowledge and innovation in landscape research and practice. Landscape Ecology 24(8):989-992. http:// dx.doi.org/10.1007/s10980-009-9393-1

Musacchio, L. R. 2009a. The scientific basis for the design of landscape sustainability: a conceptual framework for translational landscape research and practice of designed landscapes and the six Es of landscape sustainability. Landscape Ecology 24(8):993-1013. http://dx.doi.org/10.1007/s10980-009-9396y

Naveh, Z. 2001. Ten major premises for a holistic conception of multifunctional landscapes. Landscape and Urban Planning 57 (3):269-284. http://dx.doi.org/10.1016/S0169-2046(01)00209-2

Naveh, Z., and A. S. Lieberman. 1984. Landscape ecology. theory and application. Springer, New York, New York, USA.

O'Farrell, P. J., and P. M. Anderson. 2010. Sustainable multifunctional landscapes: a review to implementation. Current Opinion in Environmental Sustainability 2(1-2):59-65. http://dx. doi.org/10.1016/i.cosust.2010.02.005

Parrott, L., and W. S. Meyer. 2012. Future landscapes: managing within complexity. Frontiers in Ecology and the Environment 10 (7):382-389. http://dx.doi.org/10.1890/110082

Pearce, D. 2002. An intellectual history of environmental economics. Annual Review of Energy and the Environment 27 (1):57-81. http://dx.doi.org/10.1146/annurev.energy.27.122001.083429

Pearson, D. M., and J. T. Gorman. 2010. Exploring the relevance of a landscape ecological paradigm for sustainable landscapes and livelihoods: a case-application from the Northern Territory Australia. Landscape Ecology 25(8):1169-1183. http://dx.doi. org/10.1007/s10980-010-9498-6

Pfund, J.-L. 2010. Landscape-scale research for conservation and development in the tropics: fighting persisting challenges. Current Opinion in Environmental Sustainability 2(1-2):117-126. http://dx. doi.org/10.1016/j.cosust.2010.03.002

Pfund, J.-L., P. Koponen, T. O’Connor, J.-M. Boffa, M. van Noordwijk, and J.-P. Sorg. 2008. Biodiversity conservation and sustainable livelihoods in tropical forest landscapes. Pages 297-322 in R. Lafortezza, G. Sanesi, J. Chen, and T. R. Crow, editors. Patterns and processes in forest landscapes. Springer, Dordrecht, The Netherlands. http://dx.doi.org/10.1007/978-1-4020-8504-8 17

Pickett, S. T. A., and M. L. Cadenasso. 1995. Landscape ecology: spatial heterogeneity in ecological systems. Science 269 (5222):331-334. http://dx.doi.org/10.1126/science.269.5222.331

Pijanowski, B. C., L. R. Iverson, C. A. Drew, H. N. N. Bulley, J. M. Rhemtulla, M. C. Wimberly, A. Bartsch, and J. Peng. 2010. Addressing the interplay of poverty and the ecology of landscapes: a Grand Challenge Topic for landscape ecologists? Landscape Ecology 25(1):5-16. http://dx.doi.org/10.1007/s10980-009-9415$\underline{Z}$

Potschin, M., and R. Haines-Young. 2006. "Rio+10", sustainability science and landscape ecology. Landscape and Urban Planning 75(3-4):162-174. http://dx.doi.org/10.1016/j. landurbplan.2005.03.005

Pressey, R. L., and M. C. Bottrill. 2009. Approaches to landscapeand seascape-scale conservation planning: convergence, contrasts and challenges. Oryx 43(4):464. http://dx.doi.org/10.1017/ S0030605309990500 
Rittel, H. W. J., and M. M. Webber. 1973. Dilemmas in a general theory of planning. Policy Sciences 4(2):155-169. http://dx.doi. org/10.1007/BF01405730

Rittel, H. W., and M. M. Webber. 1984. Planning problems are wicked. Pages 135-144 in N. Cross, editor. Developments in design methodology. John Wiley and Sons, New York, New York, USA.

Robinson, J. 2004. Squaring the circle? Some thoughts on the idea of sustainable development. Ecological Economics 48(4):369-384. http://dx.doi.org/10.1016/j.ecolecon.2003.10.017

Romero, C., S. Athayde, J.-G. E. Collomb, M. DiGiano, M. Schmink, S. Schramski, and L. Seales. 2012. Conservation and development in Latin America and Southern Africa: setting the stage. Ecology and Society 17(2): 17. http://dx.doi.org/10.5751/ ES-04863-170217

Sayer, J. 2005. Ecosystem services of tropical landscapes. Pages 5-9 in Integrated management of environmental services in humandominated tropical landscapes. CATIE, Turrialba, Costa Rica.

Sayer, J. 2009. Reconciling conservation and development: are landscapes the answer? Biotropica 41(6):649-652. http://dx.doi. org/10.1111/j.1744-7429.2009.00575.x

Sayer, J., G. Bull, and C. Elliott. 2008. Mediating forest transitions: 'grand design' or 'muddling through'. Conservation \& Society 6(4):320-327. http://dx.doi.org/10.4103/0972-4923.49195

Sayer, J., T. Sunderland, J.-L. Ghazoul, J.-L. Pfund, D. Sheil, E. Meijaard, M. Venter, A. K. Boedhihartono, M. Day, C. Garcia, C. van Oostenj, and L. E. Buck. 2013. Ten principles for a landscape approach to reconciling agriculture, conservation, and other competing land uses. Proceedings of the National Academy of Sciences of the United States of America 110(21):8349-8356. http://dx.doi.org/10.1073/pnas.1210595110

Schaich, H., C. Bieling, and T. Plieninger. 2010. Linking ecosystem services with cultural landscape research. GAIAEcological Perspectives for Science and Society 19(4):269-277.

Scherr, S., S. A. Shames, and R. Friedman. 2013. Defining integrated landscape management for policy Makers. Ecoagriculture Policy Focus. No. 10. Ecoagriculture Partners, Washington, D.C., USA. [online] URL: http://ecoagriculture.org/ publication details.php?publicationID $=547$

Scherr, S. J., and J. A. McNeely. 2008. Biodiversity conservation and agricultural sustainability: towards a new paradigm of 'ecoagriculture' landscapes. Philosophical Transactions of the Royal Society B: Biological Sciences 363(1491):477-494. http:// dx.doi.org/10.1098/rstb.2007.2165

Stringer, L. C., A. J. Dougill, E. Fraser, K. Hubacek, C. Prell, and M. S. Reed. 2006. Unpacking "participation" in the adaptive management of social-ecological systems: a critical review. Ecology and Society 11(2): 39. [online] URL: http://www. ecologyandsociety.org/vol11/iss2/art39/

Tallis, H., P. Kareiva, M. Marvier, and A. Chang. 2008. An ecosystem services framework to support both practical conservation and economic development. Proceedings of the National Academy of Sciences of the United States of America 105(28):9457-9464. http://dx.doi.org/10.1073/pnas.0705797105
Terkenli, T. S. 2001. Towards a theory of the landscape: the Aegean landscape as a cultural image. Landscape and Urban Planning 57(3):197-208. http://dx.doi.org/10.1016/S0169-2046 (01)00204-3

Termorshuizen, J. W., and P. Opdam. 2009. Landscape services as a bridge between landscape ecology and sustainable development. Landscape Ecology 24(8):1037-1052. http://dx.doi. org/10.1007/s10980-008-9314-8

Tress, B., and G. Tress. 2001. Capitalising on multiplicity: a transdisciplinary systems approach to landscape research. Landscape and Urban Planning 57(3):143-157. http://dx.doi. org/10.1016/S0169-2046(01)00200-6

Tress, B., G. Tress, H. Dácamps, and A. M. d'Hauteserre. 2001. Bridging human and natural sciences in landscape research. Landscape and Urban Planning 57(3):137-141. http://dx.doi. org/10.1016/S0169-2046(01)00199-2

Turner, M. G. 1989. Landscape ecology: the effect of pattern on process. Annual Review of Ecology and Systematics 20:171-197. http://dx.doi.org/10.1146/annurev.es.20.110189.001131

Turner, M. G. 2005. Landscape ecology: what is the state of the science? Annual Review of Ecology, Evolution, and Systematics 36:319-344. http://dx.doi.org/10.1146/annurev.ecolsys.36.102003.152614

United Nations Environment Programme (UNEP). 2011. Report on how to improve sustainable use of biodiversity in a landscape perspective: executive summary (UNEP/CBD/SBSTTA/15/13). United Nations Environment Programme Subsidiary Body on Scientific, Technical and Technological Advice, 15th Meeting, Montreal, Canada, November 7-11. UNEP, Nairobi, Kenya. [online] URL: http://www.cbd.int/doc/meetings/sbstta/sbstta-15/ official/sbstta-15-13-en.pdf

Vaccaro, I., and K. Norman. 2008. Social sciences and landscape analysis: opportunities for the improvement of conservation policy design. Journal of Environmental Management 88 (2):360-371. http://dx.doi.org/10.1016/j.jenvman.2007.03.007

Vance, R. B. 1929. The concept of the region. Social Forces 8 (2):208-218. http://dx.doi.org/10.2307/2569581

Viaud, V., P. Merot, and J. Baudry. 2004. Hydrochemical buffer assessment in agricultural landscapes: from local to catchment scale. Environmental Management 34(4):559-573. http://dx.doi. org/10.1007/s00267-004-0271-y

Walters, C. 1986. Adaptive management of renewable resources. Macmillan, New York, New York, USA.

Weber, E. P., and A. M. Khademian. 2008. Wicked problems, knowledge challenges, and collaborative capacity builders in network settings. Public Administration Review 68(2):334-349. http://dx.doi.org/10.1111/j.1540-6210.2007.00866.x

Wells, M. P., and T. O. McShane. 2004. Integrating protected area management with local needs and aspirations. Ambio 33 (8):513-519. http://dx.doi.org/10.1639/0044-7447(2004)033[0513: IPAMWL]2.0.CO;2

World Bank. 2001. What is sustainable development. World Bank Group, Development Education Program, Washington, D.C., USA. [online] URL: http://www.worldbank.org/depweb/english/ $\underline{\text { sd.html }}$ 
World Commission on Environment and Development. 1987. Our common future. Oxford University Press, Oxford, UK.

World Wildlife Fund (WWF). 2014. A mosaic of landscapes. WWF International, Gland, Switzerland. [online] URL: http:// wwf.panda.org/what we do/where we work/eastern himalaya/about/ landscapes/

Wu, J. 2006. Landscape ecology, cross-disciplinarity, and sustainability science. Landscape Ecology 21(1):1-4. http://dx.doi. org/10.1007/s10980-006-7195-2

Wu, J. 2010. Landscape of culture and culture of landscape: does landscape ecology need culture? Landscape Ecology 25 (8):1147-1150. http://dx.doi.org/10.1007/s10980-010-9524-8

Wu, J. 2013a. Key concepts and research topics in landscape ecology revisited: 30 years after the Allerton Park workshop. Landscape Ecology 28(1):1-11. http://dx.doi.org/10.1007/s10980-012-9836y

Wu, J. 2013b. Landscape sustainability science: ecosystem services and human well-being in changing landscapes. Landscape Ecology 28(6):999-1023. http://dx.doi.org/10.1007/s10980-013-9894-9

Wu, J., and R. Hobbs. 2002. Key issues and research priorities in landscape ecology: an idiosyncratic synthesis. Landscape Ecology 17(4):355-365. http://dx.doi.org/10.1023/A:1020561630963

Wu, J., and O. L. Loucks. 1995. From balance of nature to hierarchical patch dynamics: a paradigm shift in ecology. Quarterly Review of Biology 70(4):439-466. http://dx.doi. org/10.1086/419172

Zexian, Y., and Y. Xuhui. 2010. A revolution in the field of systems thinking - a review of Checkland's system. Systems Research and Behavioral Science 27(2):140-155. http://dx.doi.org/10.1002/ sres. 1021 
Appendix 1 Structured literature review methods

A structured literature review was conducted to examine how landscape approaches are discussed in the literature, specifically focusing on conceptual frameworks and explicitly defined landscape approaches. Three main search terms were used in the Web of Science and Google Scholar search sites to identify articles selecting only articles providing some form of landscape-scale approach for resource management, which included both human and natural systems (Figure 2). The fourth set of search terms was only queried in Web of Science, as Google Scholar didn't provide very relevant results.

A range of different complications of search terms were preliminarily tested before coming up with the final set of three which were found to provide the most relevant results. Some sets of terms initially tested included: whole AND landscape* AND approach; integrated AND landscape* AND management; "landscape mosaic" AND livelihood*; "landscape mosaics" AND livelihood*; "landscape approach" AND livelihood* AND "case study"; ecosystem* service* approach*.

Google Scholar and Web of Science were chosen as the two search sites after reviewing a range of relevant search databases including: AGRICOLA, CAB Direct, FAO, Academic Search Complete, BIOSIS preview, AgEcon Search, Environmental Sciences and Pollution Management, Social Sciences in Forestry. Web of Science returned more specific results drawing from high impact, cross-disciplinary, international research complemented by Google Scholar providing a much broader inventory of research to ensure any important relevant articles were not missed. The first one hundred hits, sorted by relevance, for each set of search terms were reviewed. Articles were initially screened based upon their title and abstract (first selection), and then further screened based upon content in the text (second selection) (Figure A1.1).

Originally three categories of articles were screened for. This included: 1) landscape approaches or analyses which provided some level of insight into taking a landscapescaled approach including lessons learned from management activities or a set of suggested key principles; 2) conceptual frameworks for landscape-scale approaches addressing some aspect of resource management; and 3) case studies of resource management activities implemented at a landscape scale. The last category was dropped from the study design before analysis of the articles as it was originally included for a separate analysis that was determined beyond the scope of the study after obtaining search results. Additionally a limited number of papers that identified areas for further research or research priorities related to landscape-scale resource management were included as deemed highly relevant. A total of 23 articles were selected from the literature review to be included in the analysis. After all 23 articles were read in detail other relevant citations were noted and these articles were also reviewed. 20 additional papers were added to the analysis using this snowballing method resulting in a total of 43 articles (Figure A1.1). 


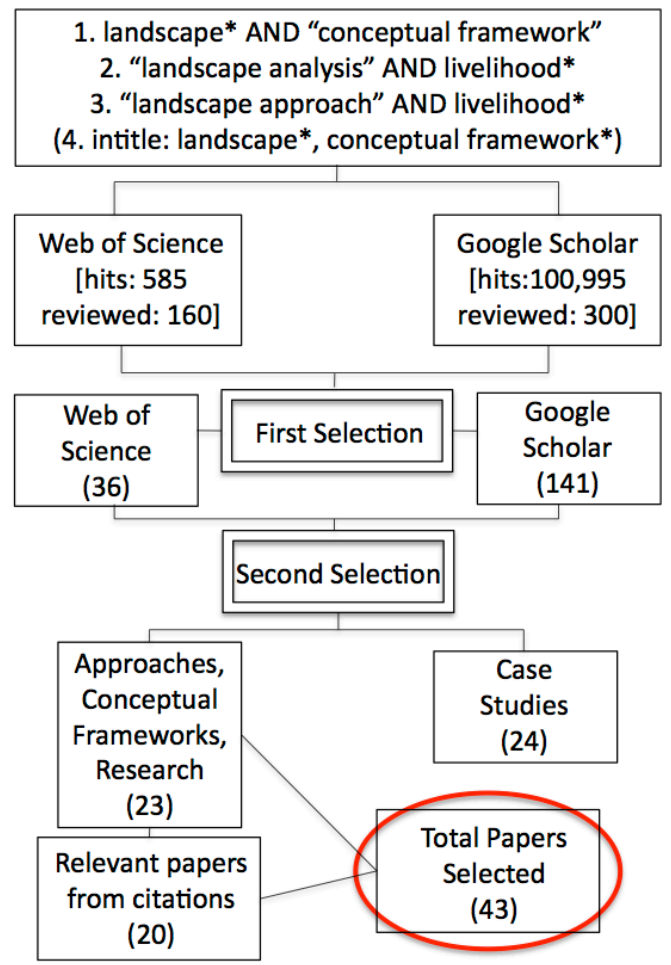

Figure A1.1 Diagram of the article selection process with the four sets of search terms, the number of hits returned from the two search sites and the number of articles selected at each stage of the process. The second and third sets of search terms contain the word 'livelihood', chosen to help find articles that included human systems as stipulated in the inclusion criteria.

The papers included in the review each provided a set of guidelines, principles or recommendations. These were developed for four different overarching objectives: to inform and further develop landscape research (e.g., Wu and Hobbs 2002, Chazdon et al. 2009, Pfund 2010, Pijanowski et al. 2010), to improve landscape-scale planning processes (e.g., Klug 2012, Gomez-Sal et al. 2003, Pressy and Bottrill 2009, Pearson and Gorman 2010), to guide landscape management (e.g., Wyborn 2009, Duff et al. 2009, Frost et al. 2006, Fischer et al. 2006) and to provide an alternative conceptual design of a landscape (e.g., Field et al. 2003, Terkenli 2001, Musacchio 2009a, Naveh 2001). Different categories of information extracted from the papers, such as the definition/interpretation of landscape, were examined individually and then compared across papers to identify convergences and divergences between them. The top six crosscutting concepts indentified are as follows: 1) complexity, 2) interdisciplinarity or transdisciplinarity, 3) sustainability, 4) participation, 5) tradeoffs and 6) holism. As the selection and analysis work was completed solely by the first author there may have been both selection and observation bias present in this process. Furthermore the total of 43 articles is a limited sample size compared to the number of articles that exist relating to landscapes and landscape approaches. This set of 43 articles therefore represents a select set of articles with an emphasis on conceptual frameworks and guidelines for taking a landscape approach in complex social-ecological systems. 
Articles included in the review:

Ahern, J. 2005. Theories, methods and strategies for sustainable landscape planning. In Tress et al. (eds) From landscape research to landscape planning: aspects of integration, education and application. Springer, Dordrecht, Netherlands, 119-131.

Antrop, M. 2000. Background concepts for integrated landscape analysis. Agriculture, Ecosystems \& Environment 77(1)17-28.

Antrop, M. 2006. Sustainable landscapes: contradiction, fiction or utopia? Landscape and Urban Planning 75(3-4):187-197.

Bastian, O., D. Haase, and K. Grunewald. 2012. Ecosystem properties, potentials and services - The EPPS conceptual framework and an urban application example. Ecological Indicators 21:7-16.

Bohnet, I., and D. M. Smith. 2007. Planning future landscapes in the Wet Tropics of Australia: A social-ecological framework. Landscape and Urban Planning 80(12):137-152.

Bowd, R. et al. 2012. The Identification of Potential Resilient Estuary-based Enterprises to Encourage Economic Empowerment in South Africa: a Toolkit Approach. Ecology and Society 17(3):15.

Chazdon, R. L. et al. 2009. Beyond Reserves: A Research Agenda for Conserving Biodiversity in Human-modified Tropical Landscapes. Biotropica 41(2):142-153.

Duff, G. et al. 2009. A collaborative design to adaptively manage for landscape sustainability in north Australia: lessons from a decade of cooperative research. Landscape Ecology 24(8):1135-1143.

Field, D. R. et al. 2003. Reaffirming Social Landscape Analysis in Landscape Ecology: A Conceptual Framework. Society \& Natural Resources 16(4):349-361.

Fischer, J., D. B. Lindenmayer, and A. D. Manning. 2006. Biodiversity, ecosystem function, and resilience: ten guiding principles for commodity production landscapes. Frontiers in Ecology and the Environment 4(2):80-86.

Frost, P. et al. 2006. Landscape-scale approaches for integrated natural resource management in tropical forest landscapes. Ecology and Society 11(2): 30.

Ghazoul, J., C. Garcia, and C. G. Kushalappa. 2009. Landscape labelling: A concept for next-generation payment for ecosystem service schemes. Forest Ecology and Management 258(9): 1889-1895.

Gómez-Sal, A., J.-A. Belmontes, and J.-M. Nicolau. 2003. Assessing landscape values: a proposal for a multidimensional conceptual model. Ecological Modelling 168(3):319-341.

Klug, H. 2012. An integrated holistic transdisciplinary landscape planning concept after the Leitbild approach. Ecological Indicators 23:616-626. 
Le, Q. B. et al. 2008. Land-Use Dynamic Simulator (LUDAS): A multi-agent system model for simulating spatio-temporal dynamics of coupled human-landscape system. I. Structure and theoretical specification. Ecological Informatics 3(2):135-153.

Makhzoumi, J. and G. Pungetti. 2008. Landscape Strategies. In I. Vogiatzakis, G. Pungetti, and A. M. Mannion (eds) Mediterranean Island Landscapes. Springer Science+Business Media B.V., 325-348.

Milder, J. C. et al. 2011. Landscape Approaches to Achieving Food Production Natural Resource Conservation, and the Millennium Development Goal. In J. C. Ingram, F. DeClerck, and C. Rumbaitis del Rio (eds). Integrating Ecology and Poverty Reduction. Springer, Boston, MA, USA, 77-108.

Musacchio, L. R. 2009a. The scientific basis for the design of landscape sustainability: A conceptual framework for translational landscape research and practice of designed landscapes and the six Es of landscape sustainability. Landscape Ecology 24(8):9931013.

Musacchio, L. R. 2009b. The ecology and culture of landscape sustainability: emerging knowledge and innovation in landscape research and practice. Landscape Ecology 24(8):989-992.

Nassauer, J. I., and P. Opdam. 2008. Design in science: extending the landscape ecology paradigm. Landscape Ecology 23(6):633-644.

Naveh, Z. 2001. Ten major premises for a holistic conception of multifunctional landscapes. Landscape and urban planning 57(3):269-284.

O'Farrell, P. J., and P. M. Anderson. 2010. Sustainable multifunctional landscapes: a review to implementation. Current Opinion in Environmental Sustainability 2(12):59-65.

Parrott, L., and W. S. Meyer. 2012. Future landscapes: managing within complexity. Frontiers in Ecology and the Environment 10(7):382-389.

Pearson, D. M., and J.T. Gorman. 2010. Exploring the relevance of a landscape ecological paradigm for sustainable landscapes and livelihoods: A case-application from the Northern Territory Australia. Landscape Ecology 25(8):1169-1183.

Pfund, J.-L. 2010. Landscape-scale research for conservation and development in the tropics: fighting persisting challenges. Current Opinion in Environmental Sustainability 2(1-2):117-126.

Pfund, J.-L. et al. 2008. Biodiversity conservation and sustainable livelihoods in tropical forest landscapes. In Lafortezza et al. (eds). Patterns and Processes in Forest Landscapes. Springer, Netherlands ,297-322 .

Pijanowski, B.C. et al. 2010. Addressing the interplay of poverty and the ecology of landscapes: a Grand Challenge Topic for landscape ecologists? Landscape Ecology 25(1):5-16.

Potschin, M., and R. Haines-Young. 2006. "Rio+10," sustainability science and Landscape Ecology. Landscape and Urban Planning 75(3-4):162-174. 
Pressey, R. L., and M. C. Bottrill. 2009. Approaches to landscape- and seascape-scale conservation planning: convergence, contrasts and challenges. Oryx 43(4):464.

Romero, C. et al. 2012. Conservation and Development in Latin America and Southern Africa: Setting the Stage. Ecology and Society 17(2): 17.

Saunders, D. A., and S. V. Briggs. 2002. Nature grows in straight lines - or does she? What are the consequences of the mismatch between human-imposed linear boundaries and ecosystem boundaries? An Australian example. Landscape and Urban Planning 61(2):71-82.

Sayer, J. 2005. Ecosystem services of tropical landscapes. Integrated management of environmental services in human-dominated tropical landscapes. CATIE. Turrialba, Costa Rica 49.

Sayer, J. 2009. Reconciling Conservation and Development: Are Landscapes the Answer? Biotropica 41(6):649-652.

Sayer, J., G. Bull, and C. Elliott. 2008. Mediating Forest Transitions:' Grand Design' or' Muddling Through'. Conservation and Society 6(4):320-327.

Schaich, H., C. Bieling, and T. Plieninger. 2010. Linking ecosystem services with cultural landscape research. GAIA-Ecological Perspectives for Science and Society 19(4):269-277.

Scherr, S. J. and J. A. McNeely. 2008. Biodiversity conservation and agricultural sustainability: towards a new paradigm of "ecoagriculture" landscapes. Philosophical Transactions of the Royal Society B: Biological Sciences 363(1491):477-494.

Terkenli, T. S. 2001. Towards a theory of the landscape: the Aegean landscape as a cultural image. Landscape and Urban Planning 57(3):197-208.

Termorshuizen, J. W., and P. Opdam. 2009. Landscape services as a bridge between landscape ecology and sustainable development. Landscape Ecology 24(8):10371052.

Tress, B., and G. Tress. 2001. Capitalising on multiplicity: a transdisciplinary systems approach to landscape research. Landscape and Urban Planning 57(3):143-157.

Tress, B. et al. 2001. Bridging human and natural sciences in landscape research. Landscape and Urban Planning 57(3):137-141.

Vaccaro, I., and K. Norman. 2008. Social Sciences and landscape analysis: Opportunities for the improvement of conservation policy design. Journal of Environmental Management 88(2):360-371.

$\mathrm{Wu}, \mathrm{J}$, and R. Hobbs. 2002. Key issues and research priorities in landscape ecology: an idiosyncratic synthesis. Landscape Ecology 17(4):355-365.

Wyborn, C. 2011. Landscape scale ecological connectivity: Australian survey and rehearsals. Pacific Conservation Biology 17(2):121-131. 